\title{
Gertruda Uścińska*
}

\section{Prawne aspekty dotyczące swobody przemieszczania się pracowników w Unii Europejskiej}

\section{Wprowadzenie}

Radania europejskie $^{1}$ dotyczące pojęcia pracownika migrującego obej¿mują wiele aspektów. W szczególności ważne są badania o charakterze prawnym, są one bowiem istotne dla ustalenia zakresu terminu „pracownik" w prawie UE oraz konsekwencji dla prawa krajowego i praktyki jego stosowania. Należy dodać, że definicja pracownika w prawie państw członkowskich jest węższa od definicji unijnej. Przepisy prawne państw członkowskich uniemożliwiają $\mathrm{w}$ wielu przypadkach podjęcie pracy pracownikom migrującym, a także nabycie prawa do świadczeń socjalnych. Sprawy te wymagają w przyszłości badań.

\section{Pracownik migrujący - pojęcie $\mathrm{w}$ prawie UE}

O przemieszczaniu się (migracji) mówimy w przypadku, gdy pracownik przemieścił się z jednego do drugiego państwa członkowskiego UE, ujmując w tym pojęciu migrację do innego państwa członkowskiego w celu podjęcia pracy, powrót do własnego państwa po zaprzestaniu wykonywania pracy za granicą (reemigracja) oraz zamieszkiwanie w jednym państwie członkowskim i wykonywanie pracy w innym państwie członkowskim w tym samym czasie ${ }^{2}$.

* Prof. nadzw. dr hab. w Zakładzie Prawa Pracy i Zabezpieczenia Społecznego Instytutu Pracy i Spraw Socjalnych; prof. Uniwersytetu Warszawskiego.

${ }^{1}$ Chodzi o badaczy europejskich skupionych w projekcie Komisji Europejskiej pn. „Free Movement of Workers and Social Security Coordination” (FreSsco), do których należy także autorka.

${ }^{2}$ Na podstawie F. Van Overmeiren (ed.), C. O' Brien, E. Spaventa, Y. Jorens, B. Schulte, Analytical Report 2014. The notions of obstacle and discrimination under EU law on free 
Swoboda przemieszczenia się pracowników, której ochronę zapewnia art. 45 Traktatu o funkcjonowaniu Unii Europejskiej, stanowi jedną z fundamentalnych zasad Unii Europejskiej. Chociaż art. 45 TFUE w sposób jasny odnosi się do konkretnych praw pracowników, ich uregulowanie znajduje się także w prawodawstwie pochodnym (dyrektywa 2004/38, rozporządzenie (UE) nr 492/11 oraz rozporządzenia (WE) nr 883/2004 i nr 987/2009)33. Natomiast kluczowe pojęcia dotyczące zakresu stosowania zasady swobodnego przemieszczania się pracowników wywodzą się przede wszystkich z orzecznictwa Europejskiego Trybunału Sprawiedliwości ${ }^{4}$.

Artykuł 45 TFUE stosuje się do pracowników migrujących (przemieszczających się), tj. osób świadczących pracę dla innej osoby i pod jej nadzorem w zamian za wynagrodzenie, zakładając, że nie ma ona charakteru jedynie drugorzędnego (pomocniczego) i marginalnego. Kategoria ta obejmuje osoby zatrudnione $\mathrm{w}$ pełnym i w niepełnym wymiarze czasu (bez względu na liczbę godzin pracy), pracowników sezonowych, pracowników przygranicznych, pracujących uczniów, studentów i osoby poszukujące pracy. Artykuł 45 nie obejmuje pracy wykonywanej bez wynagrodzenia, w tym wolontariatu lub opieki nad członkiem rodziny. Pozostaje kwestią otwarta, czy artykuł ten powinien mieć zastosowanie w przypadku staży i innych rodzajów pracy bez wynagrodzenia, których celem jest ułatwienie dostępu do rynku płatnej pracy.

Chociaż pojęcie pracownika zostało zdefiniowane szeroko, pojawiają się pewne niejasności, w szczególności w odniesieniu do pracy podejmowanej ze szczególnych pobudek lub w szczególnych okolicznościach, np. w ramach programów reintegracji społecznej bądź rehabilitacji zawodowej. Do państwa właściwego należy uznanie, czy w danej sytuacji konkretna osoba spełnia warunki przyznania jej statusu pracownika. Trzeba

movement of workers, Report prepared under FreSsco Project. European Union, http://ec.europa.eu/social/main.jsp?catId=1097\&langId=en, s. 4 i n., s. 15 i nast.

3 Dyrektywa 2004/38/WE Parlamentu Europejskiego i Rady z dnia 29 kwietnia 2004 r. w sprawie prawa obywateli Unii i członków ich rodzin do swobodnego przemieszczania się i pobytu na terytorium Państw Członkowskich, zmieniająca rozporządzenie (EWG) nr 1612/68 i uchylająca dyrektywy 64/221/EWG, 68/360/EWG, 72/194/EWG, 73/148/ EWG, 75/34/EWG, 75/35/EWG, 90/364/EWG, 90/365/EWG i 93/96/EWG (DzUrz UE L 158 z 30.04.2004, s. 77); Rozporządzenie Parlamentu Europejskiego i Rady (UE) nr 492/2011 z dnia 5 kwietnia 2011 r. w sprawie swobodnego przepływu pracowników wewnątrz Unii (DzUrz UE L 141 z 27.05.2011, s. 1); Rozporządzenie Parlamentu Europejskiego i Rady (WE) nr 883/2004 z dnia 29 kwietnia 2004 r. w sprawie koordynacji systemów zabezpieczenia społecznego (DzU L 200 z 07.06.2004, s. 1); Rozporządzenie Parlamentu Europejskiego i Rady (WE) nr 987/2009 z dnia 16 września 2009 r. dotyczące wykonywania rozporządzenia (WE) nr 883/2004 w sprawie koordynacji systemów zabezpieczenia społecznego (DzU L 284 z 10.10.2009, s. 1).

${ }^{4}$ G. Uścińska, Zabezpieczenie społeczne osób korzystajacych z prawa do przemieszczania się w Unii Europejskiej, Wolters Kluwer, Warszawa 2013, s. 72 i nast.

${ }_{5}$ Analytical Report 2014, s. 15 i nast. 
podkreślić, że status ten niesie ze sobą szereg praw i przywilejów, w tym przede wszystkim zakaz dyskryminacji, dostęp do świadczeń społecznych oraz korzyści socjalnych, bezwarunkowe prawo do zamieszkiwania w państwie goszczącym i inne ${ }^{6}$.

Praca musi wiązać się z wynagrodzeniem, jednak samo pojęcie wynagrodzenia okazuje się elastyczne. Pozwala na zakwalifikowanie jako wynagrodzenia nawet takich korzyści, jak np. zakwaterowanie. Pewne rodzaje pracy (przykładowo praca wykonywana w ramach stażu), chociaż niewątpliwie mają wartość ekonomiczną zarówno dla odbiorcy pracy, jak i dla osoby wykonującej pracę, powodują problemy w ich zakwalifikowaniu. Brak w umowie czy porozumieniu ustaleń dotyczących wynagrodzenia za taką pracę wyklucza ją z zakresu przedmiotowego pracownika migrującego. Może to w konsekwencji pozostawić sporą grupę osób wykonujących taką pracę bez ochrony $\mathrm{w}$ prawie europejskim. Z badań europejskich wynika, że dotyczy to dużej części sektora ekonomicznego państw członkowskich UE7. Co więcej, państwo członkowskie może definiować kategorię pracownika w ustawodawstwie krajowym w sposób mniej lub bardziej restrykcyjny, co może skutkować kwalifikowaniem wielu kategorii osób wykonujących pracę jako osób w świetle prawa nieaktywnych ekonomicznie i $\mathrm{w}$ rezultacie pozwalać na stosowanie wobec nich zasad pośrednio dyskryminujących, które nie miałyby zastosowania, gdyby chodziło o pracowników migrujących ${ }^{8}$.

Według badaczy europejskich stosowanie art. 45 TFUE w kontekście dostępu do rynku pracy i do świadczeń wspierających dostęp do rynku pracy powinno przede wszystkim pomagać w sytuacji, kiedy największą barierą w przemieszczeniu się pracowników jest w ogóle brak możliwości podjęcia pracy $\mathrm{w}$ innym kraju, a potem trudności związane $\mathrm{z}$ odzyskaniem statusu pracownika po utracie zatrudnienia. Jego znaczenie należy widzieć również w kontekście prawa do świadczeń, których celem jest ułatwienie i podtrzymanie dostępu do rynku pracy, a odmowa ich przyznania może być uznana za pośrednią dyskryminację. Z kolei rozwiązania

${ }^{6}$ Ibidem, s. 16 i nast.

7 Ibidem.

8 Według badaczy europejskich Komisja Europejska powinna być gotowa do kontrolowania w państwach członkowskich restrykcji stosowanych w celu ograniczenia zakresu definicji pracy wykonywanej przez osoby migrujące, $\mathrm{w}$ tym restrykcji, które negatywnie mogą odbić się na pracy wykonywanej w niepełnym wymiarze czasu. To samo tyczy się nietypowych umów o pracę, na przykład umów nie określających czasu pracy (zero-hourscontracts). Pojawiają się również problemy związane ze statusem obowiązkowych praktyk zawodowych (compulsory work placements) przy ustalaniu prawa do zasiłków.

Komisja powinna również być w stanie i w gotowości mierzyć poziom dyskryminacji pracowników migrujących w momencie, gdy stają się bezrobotni, i kwestionować wszelkie restrykcyjne zapisy ograniczające możliwość zachowania (retention) statusu pracownika. Analytical Report 2014, s. 16 i nast. 
prawne państw członkowskich skutkujące utrudnieniami w dostępie do rynku pracy dla własnych obywateli, którzy wcześniej pracowali za granicą (w innym państwie członkowskim), powinny zostać zidentyfikowane i zmienione ${ }^{9}$. Artykuł 45 TFUE zakazuje wszelkich przepisów w ustawodawstwie krajowym bezpośrednio dyskryminujących na podstawie kryterium narodowości (np. przepisów w rodzaju: „tylko obywatele danego państwa moga pracować w określonej instytucji").

Wreszcie art. 45 TFUE nie dopuszcza istnienia barier/przeszkód/restrykcji co do możliwości pracownika w zakresie przemieszczania się i dostępu do rynku pracy (pracownik narodowości polskiej, po powrocie do kraju po przepracowaniu pewnego okresu w innym państwie członkowskim, nie jest uprawniony do niektórych świadczeń albo: stosowanie zasady, że pracownik nie może być zatrudniony przez więcej niż jednego pracodawcę lub w więcej niż jednym państwie członkowskim). Takie ograniczenia mogą być stosowane jedynie na podstawie zasady dobra publicznego.

Chociaż istnieje wiele badań naukowych i opracowań przyczyniających się do rozwoju doktryny prawnej, od podejścia skupionego na dyskryminacji do podejścia skupionego na barierach i przeszkodach, to warto zauważyć, że podejście oparte na kryterium dyskryminacji daje się zastosować do większości przypadków przemieszczania się, chociaż często należy raczej mówić wówczas o dyskryminacji ze względu na przemieszczanie się (migrację) lub po prostu o dyskryminacji ze względu na narodowość ${ }^{10}$.

\section{Zakres przepisów dotyczących swobody przemieszczania się pracowników}

\subsection{Definicja i zakres pojęcia „pracownik migrujący”}

Pracownicy mają największy zakres praw związanych z zasadą równego traktowania (patrz w szczególności sprawy C-396/13 Elektrobudowa Spótka Akcyjna i C-507/12 Jessy Saint Prix). Termin „pracownik” nie docze-

${ }^{9}$ Ibidem, s. 16.

${ }^{10}$ Według orzecznictwa klasyfikacja danej zasady jako przejaw "dyskryminacji” lub jako „przeszkody” („,bariery”, „,ograniczenia”) nie powinna być rozumiana w sposób ścisły. Aby ubiegać się o uznanie jakiejś zasady za pośrednio dyskryminująca, właściwie wystarczy wykazać, że dotyczy ona większej liczby obcokrajowców i osób migrujących niż własnych obywateli danego państwa, i żaden szczególny dowód nie jest wymagany. Aby uznać jakąś zasadę za przeszkodę czy barierę, wystarczy pokazać, że może ona zniechęcać lub odstraszać pracowników od decyzji o przemieszczeniu się lub że może ona stanowić barierę w dostępie do rynku pracy. Z tego względu w praktyce zaleca się, aby sądy krajowe orzekały zarówno o dyskryminacji, jak i o przeszkodach w sposobie przepływu pracowników. Por. Analytical Report 2014, s. 17. 
kał się definicji w prawie europejskim ${ }^{11}$. Pojęcie „pracownika”, a raczej „pracownika migrującego”, zostało zdefiniowane przez Trybunał Sprawiedliwości UE w świetle zasad wywodzonych z europejskiego porząd$\mathrm{ku}$ prawnego ${ }^{12}$. Zresztą ten proces trwa, w ostatnich bowiem wyrokach TS UE takie doprecyzowanie ciągle następuje (w szczególności sprawa C-396/13 i C-507/12).

Unijne pojęcie "pracownika” zasadza się na trzech podstawowych elementach: świadczeniu pracy, wynagrodzeniu i podporządkowaniu. „Trzy kluczowe cechy stosunku pracy polegają na tym, że osoba wykonuje pracę posiadającą pewną wartość ekonomiczną dla i pod kierunkiem innej osoby w zamian za wynagrodzenie, które otrzymuje" (sprawa C-66/85 Lawrie-Blum). W świetle orzecznictwa TS UE ktoś, kto faktycznie poszukuje pracy, może zostać zaklasyfikowany jako pracownik. Niemniej prawo do zamieszkania i równego traktowania w odniesieniu do osób poszukujących pracy ma charakter warunkowy i ograniczony.

Trybunał Sprawiedliwości UE zinterpretował pojęcie "pracownika” w sposób szeroki, podkreślając, że definiuje ono zakres jednej z podstawowych swobód przyznawanych przez zapisy traktatowe. Wynika z tego, że pojęcie „pracownika” nie może być interpretowane w sposób restrykcyjny (sprawa C-53/81 Levin oraz łączone - sprawy 389/87 i 390/87 Echternach) i obejmuje osoby pracujące w pełnym wymiarze czasu, w niepełnym wymiarze czasu ${ }^{13}$, a także pracowników sezonowych i przygranicznych. Pracownicy mogą uzyskiwać przychody na poziomie i poniżej płacy minimalnej czy poniżej kwoty uznanej za minimum egzystencjalne oraz mają pełen dostęp do świadczeń i przywilejów socjalnych i podatkowych (sprawa C-139/85 Kempf), ten status pracownika daje bowiem podstawę prawną dostępu do tych świadczeń.

Aby ktoś został zakwalifikowany jako pracownik przemieszczający się w obrębie Unii Europejskiej, wykonywana przez niego praca musi mieć charakter "faktyczny i wymierny" (genuine and effective), a nie jedynie „drugorzędny (pomocniczy) i marginalny”. Praca może mieć charakter faktyczny i wymierny także wtedy, gdy produktywność jest niska, jeśli

11 Poza zastrzeżeniem, że termin ten nie obejmuje obywateli państw trzecich zamieszkujących i pracujących na terytorium państwa członkowskiego, a dotyczy jedynie obywateli państw członkowskich.

${ }_{12}$ W celu zapobiegania tworzeniu takich definicji przez państwa członkowskie, gdyż w przeciwnym razie państwo członkowskie byłyby w stanie jednostronnie zmieniać zakres obowiązywania przepisów traktatowych. Tak ujęli to badacze europejscy w Analytical Report 2014, s. 16 i nast.

${ }^{13}$ Ponieważ w wielu gałęziach gospodarki większość osób wykonujących pracę $\mathrm{w}$ niepełnym wymiarze godzin to kobiety, ich wyłączenie z zakresu stosowania art. 45 TFUE nabierałoby także charakteru dyskryminacji ze względu na płeć. 
praca wykonywana jest jedynie przez kilka godzin lub wynagrodzenie jest bardzo niskie (sprawa C-66/85 Lawrie-Blum). Przez dekady ta luźna formuła pozostała niezmieniona, a Trybunał wielokrotnie podtrzymywał swoją interpretację, że „pracownik” to pojęcie, które należy rozumieć szeroko. Nigdy też nie przyjął jakiegokolwiek kryterium de minimis, określającego wysokość wynagrodzenia lub ilość czasu pracy, preferując indywidualne podejście $\mathrm{w}$ każdym przypadku ${ }^{14}$.

Fakt, że pracownik pracował na podstawie umowy na czas określony i jedynie przez krótki okres nie wyłącza go z zakresu podmiotowego art. 45 TFUE pod warunkiem, że wykonywana praca nie miała charakteru czysto pomocniczego i marginalnego. W sprawie C-413/01 Ninni-Orasche wnioskodawca przepracował jedynie dwa i pół miesiąca. Trybunał poinformował sąd krajowy, by ten miał wzgląd jedynie na charakter aktywności ekonomicznej, tj. na to, czy była to praca faktyczna i wymierna, a nie, że była to aktywność pomocnicza, i pominął inne względy, takie jak fakt, że wnioskodawczyni podjęła pracę po wielu latach od przemieszczenia się na terytorium państwa goszczącego i zaraz po rozpoczęciu pracy uzyskała kwalifikacje umożliwiające jej podjęcie nauki na uniwersytecie (zob. sprawa C-46/12 L.N. v Styrelsen for Videregaende Uddannelser). W opinii TS UE powód, dla którego osoba decyduje się szukać pracy w innym państwie członkowskim, jest - jeśli chodzi o uznanie jej statusu jako pracownika - bez znaczenia. Tym samym nie jest ważne, że osoba zdecydowała się podjąć pracę jedynie po to, by skorzystać z obowiązujących przepisów traktatowych i tym samym z praw przyznawanych przez prawo unijne pod warunkiem, że podjęta aktywność miała charakter faktycznej i wymiernej pracy, a nie jedynie aktywności pomocniczej czy marginalnej (sprawy: C-53/81 Levin, C-109/01 Akrich, C-46/12 L.N. v Styrelsen for Videregaende Uddannelser) ${ }^{15}$.

Chociaż pojęcie „pracownika” jest skonstruowane w sposób niezwykle otwarty i przyjazny dla osób korzystających z prawa do przemieszczania się, to nadal obejmuje ono jedynie podejmowanie aktywności o charakterze faktycznej i wymiernej pracy, nie zaś aktywności na tak małą skalę lub o tak małym znaczeniu, że może ona być uznana za „marginalną i jedynie pomocniczą" (sprawy: C-53/81 Levin, C-413/01 Ninni-Orasche). W sprawie C-344/87 Bettray Trybunał uznał, że dany rodzaj aktywności nie może być uznany za faktyczną i mającą wymierną wartość pracę, jeżeli jest ona tylko i wyłącznie środkiem reintegracji społecznej lub rehabilitacji zawodowej i jeżeli celem tej płatnej aktywności, której wykonywanie dostosowane jest tak naprawdę do potrzeb indywidualnych pracownika, jest tylko

${ }^{14}$ G. Uścińska, Zabezpieczenie społeczne..., s. 72 i nast.

15 Analytical Report 2014, s. 16. 
umożliwienie odzyskania sprawności i powrotu do wykonywania zwykłej pracy lub umożliwienie prowadzenia (bardziej) normalnego życia.

W przypadku, którego dotyczyła sprawa C-456/02 Trojani, obywatel Francji zamieszkały w Belgii pracował około 30 godzin w tygodniu dla Armii Zbawienia w ramach osobistego programu reintegracji społeczno-zawodowej. W zamian za wykonywaną tam pracę otrzymywał zakwaterowanie wraz z wyżywieniem i kieszonkowe. Kiedy wystąpił o przyznanie zasiłku socjalnego, jego wniosek został odrzucony, co motywowano tym, że nie jest on pracownikiem w znaczeniu art. 45 TFUE i tym samym nie ma prawa do świadczeń z systemu pomocy społecznej. TS UE uznał, że przy określaniu, czy pracę uznać za faktyczną i wymierna, sąd krajowy powinien przede wszystkim „zbadać, czy usługi świadczone przez pana Trojani można uznać za usługi funkcjonujące na zwykłym rynku pracy". W tym celu warto przyjrzeć się statusowi i funkcjonowaniu hostelu, treści programu reintegracji społeczno-zawodowej oraz „przeanalizować i wziąć po uwagę szczegółowy charakter wykonywanych przez niego prac"16.

Zakres podmiotowy prawa do swobodnego przemieszczania się obejmuje też strony umów i kontraktów, co skutkuje tym, że pracodawca może opierać się na traktatowych przepisach dotyczących swobodnego przemieszczania się także w celu kwestionowania zasad ograniczających swobodę zatrudnianych przez niego pracowników (sprawy: C-350/96 Clean car, C-379/11 Caves Krier). Pracownicy oddelegowani, w odróżnieniu od pracowników migrujących, nie wchodzą na rynek pracy państwa goszczącego, lecz jedynie pracują $w$ nim przez pewien okres $w$ ramach usług świadczonych przez swojego pracodawcę, i traktowani są jako uczestnicy rodzimego rynku pracy. Zasady dotyczące swobodnego przemieszczania się pracowników tym samym nie dotyczą pracowników oddelegowanych, natomiast stosuje się w ich przypadku zasady dotyczące swobody przepływu usług ${ }^{17}$.

\subsection{Zachowanie statusu pracownika}

Odzwierciedleniem orzecznictwa TS UE są postanowienia przepisów prawa wtórnego, które przewidują przedłużenie i zachowanie statusu pracownika, kiedy nie jest już wykonywana aktywność ekonomiczna. W szczególności chodzi o dyrektywę 2004/38. Na jej podstawie (art. 7

16 Analytical Report 2014, s. 16 oraz G. Uścińska, Zabezpieczenie społeczne..., s. 79 i nast.

17 Jeśli chodzi o zatrudnienie i warunki pracy, to dyrektywa 96/71/WE Parlamentu Europejskiego i Rady z dnia 16 grudnia 1996 r. dotycząca delegowania pracowników w ramach świadczenia usług (DzUrz WE L 18 z 21.01.1997, s. 1) przewiduje wypracowanie kilku minimalnych wymagań i zasad, które muszą być przestrzegane w państwie goszczącym przez pracodawców, którzy decydują się oddelegować swoich pracowników. 
ust. 3) pracownik najemny zachowuje status pracownika (lub osoby pracującej na własny rachunek, jeżeli:

a) jest okresowo niezdolny do pracy z powodu choroby bądź wypadku;

b) pracownik stracił pracę nie z własnej woli, co jest należycie udokumentowane, pod warunkiem że wcześniej pracował przez co najmniej rok i jest zarejestrowany jako bezrobotny lub;

c) pracownik stracił pracę nie z własnej woli po zakończeniu umowy o pracę na czas krótszy niż rok lub został zwolniony nie z własnej woli w czasie pierwszych dwunastu miesięcy pracy, pod warunkiem że jest zarejestrowany jako poszukujący pracy we właściwym urzędzie. W takim przypadku status pracownika zostaje zachowany nie dłużej niż sześć miesięcy;

d) podjął kształcenie zawodowe po zwolnieniu z pracy. Jeżeli zwolnienie nastąpiło z przyczyn leżących po stronie pracownika, wówczas kształcenie musi pozostawać w związku z zatrudnieniem Jeżeli dany pracownik jest bezrobotny nie z własnej woli, wtedy szkolenie zawodowe nie musi być związane z wykonywaną pracą ${ }^{18}$.

\subsection{Członkowie rodziny}

Pracownik migrujący ma prawo do tego, by towarzyszyli mu członkowie rodziny. W prawie unijnym ochronie podlegają następujący członkowie rodziny: małżonek, zarejestrowany partner w przypadku, gdy goszczące państwo członkowskie rejestruje związki partnerskie, dzieci poniżej 21. roku życia, które pozostają na utrzymaniu pracownika lub jego/jej współmałżonka, a także wstępni pozostający na utrzymaniu pracowni$\mathrm{ka}^{19}$. Mają oni prawo do zamieszkania wraz z pracownikiem na terytorium państwa goszczącego, prawo do podjęcia aktywności ekonomicznej i prawo do ochrony przed dyskryminacją ze względu na narodowość w każdym przypadku, w tym w odniesieniu do świadczeń przewidzianych w systemie państwa opiekuńczego (przykładowo sprawa C-32/75 Cristini v SNC).

${ }_{18}$ Art. 7 (3) dyrektywy 2004/38.

19 Art. 3 dyrektywy 2004/38 przewiduje ponadto, że państwo członkowskie musi ułatwić dostęp i uzasadnić każdą odmowę dostępu do swojego terytorium innym członkom rodziny, którzy pozostają na utrzymaniu pracownika, a także wtedy, gdy nie są na jego utrzymaniu, ale wymagają opieki ze względu na stan zdrowia lub mieszkali pod jednym dachem z pracownikiem w państwie pochodzenia. Dotyczy to również partnera, z którym obywatel Unii pozostaje w stabilnym, odpowiednio udokumentowanym i poświadczonym związku. 


\section{Podsumowanie}

Arykuł 45 TFUE obejmuje migrujących pracowników (wykonujących pracę pod nadzorem i w zamian za wynagrodzenie). Kategoria ta odnosi się do:

- osób wykonujących pracę w pełnym wymiarze czasu;

- osób wykonujących pracę w niepełnym wymiarze czasu, bez względu na to, ile godzin w tygodniu pracuja, po warunkiem że wykonywana praca nie ma charakteru marginalnego i czysto pomocniczego;

- pracowników przygranicznych;

- pracowników sezonowych;

- osób poszukujących pracy.

Chociaż prawa tej ostatniej kategorii osób chronione są w art. 45 Traktatu, to dyrektywa 2004/38 wyłącza ich z zakresu obowiązywania zasady równego traktowania w odniesieniu do pomocy społecznej. To wyłączenie interpretowane jest jednak wąsko, osoby poszukujące pracy mają więc dostęp do zasiłków, których celem jest ułatwienie dostępu do rynku pracy. Przepisów art. 45 TFUE nie stosuje się do pracy, za którą osoba ją wykonująca nie uzyskuje wynagrodzenia, w tym pracy w ramach wolontariatu. Pozostaje kwestią otwarta, czy artykuł ten powinien mieć zastosowanie w przypadku staży i innych rodzajów pracy bez wynagrodzenia, której celem jest ułatwienie dostępu do rynku płatnej pracy.

Artykuł 45 TFUE może być wykorzystywany również przez pracodawców w celu pokonywania barier w wynajmowaniu pracowników.

Rodzina pracownika także podlega ochronie na mocy przepisów pierwotnego i pochodnego prawa UE.

\section{Bibliografia}

Uścińska G., Zabezpieczenie społeczne osób korzystających z prawa do przemieszczania się w Unii Europejskiej, Wolters Kluwer, Warszawa 2013.

Van Overmeiren F. (ed.), O'Brien C., Spaventa E., Jorens Y., Schulte B., Analytical Report 2014. The notions of obstacle and discrimination under EU law on free movement of workers, Report prepared under FreSsco Project, European Union, http://ec.europa.eu/social/ main.jsp?catId=1097\&langId=en. 


\title{
Legal Aspects of the Freedom of Movement of Workers in the European Union
}

\begin{abstract}
Summary
The chapter undertakes to analyze the notion of "migrant worker" as used in the EU law. The scope of the term is discussed on the basis of the legislation and the caselaw of the Court of Justice of the EU. As a result of the case-law, a gradual widening of the scope of the term "migrant worker" may be observed. However, this wider understanding of the term often faces challenges and obstacles from the national legislation of the EU Member States, which not only elaborate more strict definitions of the term but also provide restrictions for the application of the EU definition of the term. The future development of the legal doctrine should focus on the barriers and obstacles that impede the freedom of movement of workers. This is suggested also in the current European studies on the subject.
\end{abstract}

